\title{
Halomonas avicenniae sp. nov., isolated from the salty leaves of the black mangrove Avicennia germinans in Puerto Rico
}

Correspondence

Rafael Montalvo-Rodríguez titomontal@yahoo.com

\author{
Nelís Soto-Ramírez, ${ }^{1}$ Cristina Sánchez-Porro, ${ }^{2}$ Soniris Rosas, ${ }^{1}$ \\ Wildaomaris González, ${ }^{1}$ Marian Quiñones, ${ }^{1}$ Antonio Ventosa ${ }^{2}$ \\ and Rafael Montalvo-Rodríguez ${ }^{1}$
${ }^{1}$ Biology Department Box 9012, University of Puerto Rico, Mayagüez 00681, Puerto Rico
${ }^{2}$ Department of Microbiology and Parasitology, Faculty of Pharmacy, University of Sevilla, 41012 Sevilla, Spain

The genus Halomonas belongs to the family Halomonadaceae within the Gammaproteobacteria and at the time of writing comprised 35 species that had been isolated mainly from saline or hypersaline environments (Arahal et al., 2002; Bouchotroch et al., 2001; Dobson \& Franzmann, 1996; Garcia et al., 2004; Lee et al., 2005; Lim et al., 2004; Martínez-Cánovas et al., 2004; Martínez-Checa et al., 2005; Mata et al., 2002; Mormile et al., 1999; Quillaguaman et al., 2004; Romanenko et al., 2002; Ventosa et al., 1998; Vreeland et al., 1980; Yoon et al., 2001, 2002) or from unusual habitats such as dry mural paintings (Heyrman et al., 2002) and deep-sea hydrothermal vents (Kaye et al., 2004). Phylogenetic analysis using the $16 \mathrm{~S}$ and $23 \mathrm{~S}$ rRNA gene sequences and phenotypic studies demonstrated that this genus is very heterogeneous (Arahal et al., 2002; Mata et al., 2002). One distinct group is represented by a single species, Halomonas marisflavi (Yoon et al., 2001). To date, there have been no reports of the occurrence of members of this genus being associated with mangroves that thrive on saline habitats. Avicennia germinans is a type of mangrove that has developed mechanisms to tolerate high salt concentrations

The GenBank/EMBL/DDBJ accession number for the 16S rRNA gene sequence of strain $\mathrm{MW}^{\mathrm{a}} \mathrm{a}^{\top}$ is $\mathrm{DQ888315}$. in unstable substrates, to obtain oxygen in almost anoxic sediments and to reproduce in harsh areas. One of these mechanisms consists of the secretion of salt crystals on the leaves when the concentration is in excess of that normally present in the vascular system (Lugo \& Snedaker, 1975). In this study, we determined the taxonomic position of strain MW $2 \mathrm{a}^{\mathrm{T}}$, which was isolated from the surface of leaves of the black mangrove $A$. germinans during a microbial diversity study. As a result of our studies, the name Halomonas avicenniae sp. nov. is proposed for this novel microorganism.

Strain MW2 $\mathrm{a}^{\mathrm{T}}$ was isolated from the surface of leaves of $A$. germinans. For isolation, a total of 40 leaves were collected randomly from four trees growing near the solar salterns of Cabo Rojo, Puerto Rico. The leaves were placed in sterile bags (Whirl Pak) containing $1 \%$ phosphate buffer at $\mathrm{pH} 7$ with $15 \%(\mathrm{w} / \mathrm{v}) \mathrm{NaCl}$ and mixed. This procedure allowed suspension of the micro-organisms present in the salt crystals on the surface of the leaves. Ten millilitres of the suspension was then used to generate serial dilutions. The dilutions were poured into agar plates containing SeghalGibbons (SG) medium at $15 \% \mathrm{NaCl}$ (Seghal \& Gibbons, 1960). The inoculated plates were incubated at $30^{\circ} \mathrm{C}$. After 
3 days of incubation, colonies were selected and purified by using the quadrant streak plate method. Pure cultures were transferred to SG medium for further analysis.

The morphology of the cells was examined by using the Nomarsky technique and scanning electron microscopy with cells at the exponential phase of growth under optimal conditions. Electron microscopy was performed as described previously (Díaz-Muñoz \& MontalvoRodríguez, 2005). Gram stain was performed using both heat-fixed smears and smears fixed in $5 \%$ acetic acid (Dussault, 1955). Macroscopic properties were determined using the classical characterization of colony appearance. Optimal conditions for growth were determined by growing strain MW2 $\mathrm{a}^{\mathrm{T}}$ in SG broth supplemented with $0,5,10,15$, 20,25 and $30 \%(w / v) ~ N a C l$ at temperatures of 20, 25, 30, 35 and $40{ }^{\circ} \mathrm{C}$. The $\mathrm{pH}$ range for growth was tested using SG medium containing $5 \% \mathrm{NaCl}$ and adjusted to $\mathrm{pH} 4.0,5.0$, $6.0,7.0,8.0,9.0$ and 10.0, with the addition of the appropriate buffering capacity to each medium as described previously (Montalvo-Rodríguez et al., 2000). The cells were cultivated with constant agitation (150 r.p.m.) and growth was monitored by measuring the absorbance at $600 \mathrm{~nm}$. Cells of strain $\mathrm{MW}_{2} \mathrm{a}^{\mathrm{T}}$ are Gram-negative, non-sporeforming, motile short rods or ovals. At the exponential phase of growth in SG medium with $5 \% \mathrm{NaCl}$ at $30^{\circ} \mathrm{C}$, cells were 2-2.6 $\mu \mathrm{m}$ long and 1-2 $\mu \mathrm{m}$ wide. On SG medium with $5 \% \mathrm{NaCl}$, colonies were orange, smooth, circular/slightly irregular and convex, with an entire margin. Strain MW2 ${ }^{\mathrm{T}}$ grew at $\mathrm{NaCl}$ concentrations in the range $0-25 \%(\mathrm{w} / \mathrm{v})$ in SG medium. Growth did not occur at concentrations of $\mathrm{NaCl}$ greater than $25 \%(\mathrm{w} / \mathrm{v})$. The temperature range for growth was $12-40^{\circ} \mathrm{C}$ and the $\mathrm{pH}$ range was 5.0-9.0. Optimal growth occurred in SG medium with $5 \%(\mathrm{w} / \mathrm{v}) \mathrm{NaCl}$ at $30-35^{\circ} \mathrm{C}$ and $\mathrm{pH} 7.0-8.0$. This combination of conditions produced the shortest generation time $(1.42 \mathrm{~h})$.

All of the biochemical tests were carried out with $5 \% \mathrm{NaCl}$ and at $30^{\circ} \mathrm{C}$, unless stated otherwise. Catalase activity was determined by addition of a $1 \%(\mathrm{w} / \mathrm{v}) \mathrm{H}_{2} \mathrm{O}_{2}$ solution to colonies on SG agar medium. Oxidase activity was tested using the Dry Slide (Difco) biochemical test (MontalvoRodríguez et al., 1998). Hydrolysis of starch, Tween 80 and aesculin was determined as described by Cowan \& Steel (1965), with the addition of basal salts $[5 \% \mathrm{NaCl}, 2 \%$ $\mathrm{MgSO}_{4} .7 \mathrm{H}_{2} \mathrm{O}$ and $\left.0.2 \% \mathrm{KCl}(\mathrm{w} / \mathrm{v})\right]$ to the medium. Hydrolysis of gelatin and production of urease were determined according to Cowan \& Steel (1965). Citrate utilization was determined on Simmons' citrate medium (Simmons, 1926) supplemented with basal salts. Acid production from carbohydrates was determined using a phenol red base supplemented with $0.7 \%$ of the carbohydrate tested and basal salts. Motility was determined using SIM medium, supplemented with basal salts. Production of $\mathrm{H}_{2} \mathrm{~S}$ was determined using the API 20E system, as described previously (Yoon et al., 2001). Growth under anaerobic conditions was determined by incubating strain $\mathrm{MW} 2 \mathrm{a}^{\mathrm{T}}$ in an anaerobic chamber in SG medium with
$5 \% \mathrm{NaCl}$. Tests for sugar fermentation and enzymes (qualitative) were carried out using API $20 \mathrm{NE}$ and API ID $32 \mathrm{E}$ (bioMérieux), according to the manufacturer's instructions, with the inoculated fluid at $5 \% \mathrm{NaCl}$ and incubation at $30^{\circ} \mathrm{C}$. Nutritional features were determined using Koser medium (Koser, 1923), as modified by Ventosa et al. (1982), which contains the basal salts described above and $(\%, \mathrm{w} / \mathrm{v}): \mathrm{KNO}_{3}, 0.1 ;\left(\mathrm{NH}_{4}\right)_{2} \mathrm{HPO}_{4}, 0.1$; and $\mathrm{KH}_{2} \mathrm{PO}_{4}$, 0.05 . The filter-sterilized substrate was added to this medium at a final concentration of $0.1 \%(\mathrm{w} / \mathrm{v})$, with the exception of carbohydrates, which were used at a final concentration of $0.2 \%(w / v)$. Strain MW2 $\mathrm{a}^{\mathrm{T}}$ was able to use L-arabinose, D-cellobiose, D-fructose, D-galactose, D-glucose, maltose, D-mannose and glycerol as carbon and energy sources. Antibiotic susceptibility was determined according to the conventional Kirby-Bauer method (Bauer et al., 1966). The phenotypic characteristics of strain MW2 $\mathrm{a}^{\mathrm{T}}$ are summarized and compared with those of the type strains of related Halomonas species in Table 1 and in the species description.

For the characterization and sequencing of the 16S rRNA gene, strain MW2 $\mathrm{a}^{\mathrm{T}}$ was grown in SG medium with $5 \%$ $\mathrm{NaCl}$ and incubated at $30^{\circ} \mathrm{C}$. Genomic DNA was extracted from cells in lysis buffer followed by phenol/chloroform extraction and ethanol precipitation. The DNA was used as a template for subsequent PCR amplification. Reaction conditions and amplification protocols used were as described elsewhere (Hezayen et al., 2002). The resulting amplicon was purified using a MinElute PCR purification kit, according to the manufacturer's instructions. Purified PCR products were sequenced at a DNA sequencing facility (Macrogen, Korea). Distance analysis of the resulting DNA sequence was performed using the PHYLIP program (version 3.63; Felsenstein, 1993). Multiple-sequence alignment was performed by using the CLUSTAL $\mathrm{W}$ program with $16 \mathrm{~S}$ rRNA gene sequences of closely related organisms (as determined by BLAST analysis) (Maidak et al., 1996). The 16S rRNA gene similarity values were calculated by pairwise comparison of the sequences within the alignment. SEQBOOT was used to generate 100 bootstrapped datasets. Distance matrices were calculated with DNADIST. One hundred trees were inferred by using the neighbour-joining software. Any bias introduced by the order of sequence addition was minimized by randomizing the input order. The program CONSENSE was used to determine the most frequent branching order. The final tree was drawn using TREEVIEW (Page, 1996).

In silico analysis of strain MW2 $\mathrm{a}^{\mathrm{T}}$ using the BLAST program (National Center for Biotechnology) with an almost complete 16S rRNA gene sequence (1433 bp) revealed that this strain was related to the genus Halomonas, with the closest sequence similarity to H. marisflavi KCCM $80003^{\mathrm{T}}$ $(98.6 \%)$, a species that represents one of the various groups of this genus. 16S rRNA gene sequence similarities between strain $\mathrm{MW}^{\mathrm{T}} \mathrm{a}^{\mathrm{T}}$ and Halomonas elongata ATCC $33173^{\mathrm{T}}$, Halomonas salina DSM $5928^{\mathrm{T}}$ and Halomonas halodurans DSM $5160^{\mathrm{T}}$ were $92.8,92.8$ and $91.7 \%$, respectively. Strain 
Table 1. Phenotypic characteristics that distinguish strain $M W 2 a^{\top}$ from the type strains of other species of the genus Halomonas

Strains: 1, MW2a ${ }^{\mathrm{T}} ; 2$, H. marisflavi KCCM 80003 ${ }^{\mathrm{T}}$; 3, H. elongata ATCC $33173^{\mathrm{T}} ;$ 4, H. salina ATCC 49509 ${ }^{\mathrm{T}}$; 5 , H. halodurans DSM 5160 ${ }^{\mathrm{T}}$; 6, Halomonas halmophila DSM 5349 ${ }^{\mathrm{T}}$; 7, Halomonas marina DSM 4741 $1^{\mathrm{T}}$; , Halomonas eurihalina DSM 5720 ${ }^{\mathrm{T}}$. Data from Arahal et al. (2001, 2002), Baumann et al. (1983), Franzmann et al. (1988), Hebert \& Vreeland (1987), Mata et al. (2002), Mellado et al. (1995), Yoon et al. (2001) and this study. +, Positive; -, negative; +/-, weak reaction; ND, no data.

\begin{tabular}{|c|c|c|c|c|c|c|c|c|}
\hline Characteristic & 1 & 2 & 3 & 4 & 5 & 6 & 7 & 8 \\
\hline Cell morphology & Rods or ovals & Rods or ovals & Short rod & Short rod & Rod & Short rod & Rod & Rod \\
\hline Pigmentation & Orange & Yellow & White & Cream & None & Cream & Cream & Cream \\
\hline$\beta$-Galactosidase & + & - & + & + & - & - & + & + \\
\hline Motility & + & + & + & - & + & + & + & - \\
\hline Exopolysaccharide production & - & - & - & - & - & - & + & + \\
\hline Oxidase & - & - & - & + & + & + & - & - \\
\hline Facultative anaerobe & - & + & + & - & - & - & - & - \\
\hline \multicolumn{9}{|l|}{ Acid production from: } \\
\hline D-Glucose & + & + & + & - & + & + & + & - \\
\hline Sucrose & + & + & + & - & + & + & - & - \\
\hline Maltose & $+1-$ & + & + & - & - & + & - & - \\
\hline Mannitol & + & $+1-$ & + & - & + & + & + & - \\
\hline Xylose & + & + & - & $\mathrm{ND}$ & - & - & - & + \\
\hline D-Fructose & + & + & - & - & + & + & + & - \\
\hline Lactose & - & + & + & - & - & + & - & - \\
\hline L-Arabinose & + & + & + & - & - & + & - & - \\
\hline Nitrate reduction & - & - & + & + & - & - & - & + \\
\hline Simmons' citrate & + & + & + & + & + & - & - & + \\
\hline \multicolumn{9}{|l|}{ Hydrolysis of: } \\
\hline Gelatin & + & + & - & - & - & - & - & + \\
\hline Urea & - & - & + & + & + & - & + & + \\
\hline Tween 80 & - & - & - & - & + & - & + & + \\
\hline Aesculin & + & + & - & - & + & - & - & + \\
\hline DNA G $+C$ content $(\mathrm{mol} \%)$ & 61.5 & 59.0 & 60.5 & 64.2 & 63.2 & 63.0 & 62.8 & 65.7 \\
\hline
\end{tabular}

MW2 $\mathrm{a}^{\mathrm{T}}$ also showed low sequence similarity to Chromohalobacter salexigens DSM $3043^{\mathrm{T}}$ (93.7\%). Phylogenetic analysis using the neighbour-joining algorithm revealed that strain $\mathrm{MW}_{2} \mathrm{a}^{\mathrm{T}}$ was closely related to $H$. marisflavi, forming a branch in this cluster with a boostrap value of $100 \%$ (Fig. 1). The phylogenetic position of strain MW2a ${ }^{\mathrm{T}}$ was also confirmed in a tree generated using the maximumparsimony algorithm.

Fatty acids were analysed by using GC at the Belgian Coordinated Collections of Microorganisms, Laboratory of Microbiology of Gent (BCCM/LMG), Gent, Belgium (Kämpfer \& Kroppenstedt, 1996; Miller, 1982). Cells were cultured on SW10 medium $\left[8.1 \% \mathrm{NaCl}, 0.7 \% \mathrm{MgCl}_{2}\right.$, $0.96 \% \quad \mathrm{MgSO}_{4}, \quad 0.036 \% \mathrm{CaCl}_{2}, \quad 0.2 \% \mathrm{KCl}, \quad 0.006 \%$ $\mathrm{NaHCO}_{3}, \quad 0.0026 \% \mathrm{NaBr}, \quad 0.5 \%$ yeast extract, w/v (Difco)] (Ventosa et al., 1982) for $24 \mathrm{~h}$ at $\mathrm{pH} 7.0$ and $30^{\circ} \mathrm{C}$. The predominant fatty acids of strain $\mathrm{MW} 2 \mathrm{a}^{\mathrm{T}}$ were $\mathrm{C}_{16: 0}, \mathrm{C}_{19: 0}$ cyclo $\omega 8 c, \mathrm{C}_{18: 1} \omega 7 c$ and $\mathrm{C}_{12: 0} 3-\mathrm{OH}$. This composition is very similar to those described for other Halomonas species (Table 2).

The $\mathrm{G}+\mathrm{C}$ content of genomic DNA was determined from the mid-point value $\left(T_{\mathrm{m}}\right)$ of the thermal denaturation profile (Marmur \& Doty, 1962) using the equation of Owen \& Hill (1979), as described in detail by Ventosa et al. (1999). The DNA G + C content of strain MW2 $\mathrm{a}^{\mathrm{T}}$ was $61.5 \mathrm{~mol} \%$, which is in the range for species belonging to the genus Halomonas (Arahal \& Ventosa, 2005; Franzmann et al., 1988).

DNA-DNA hybridization studies were performed by using the competition procedure of the membrane method (Johnson, 1994), as described in detail by Mormile et al. (1999). The hybridization temperature used was $57.3^{\circ} \mathrm{C}$, which is within the limit of validity for the filter method (De Ley \& Tijtgat, 1970) and the percentage DNA-DNA relatedness was calculated according to Johnson (1994). The experiments were carried out in triplicate. The DNADNA relatedness between strain $\mathrm{MW} 2 \mathrm{a}^{\mathrm{T}}$ and $H$. marisflavi KCCM $80003^{\mathrm{T}}$ was $42 \%$, whereas the relatedness with H. elongata ATCC $33173^{\mathrm{T}}$ and H. salina DSM $5928^{\mathrm{T}}$ was 23 and $13 \%$, respectively. These levels of DNA-DNA relatedness are low enough to classify strain $\mathrm{MW} 2 \mathrm{a}^{\mathrm{T}}$ as representing a genotypically distinct species within the genus Halomonas (Wayne et al., 1987; Stackebrandt \& Goebel, 1994).

Overall, the phenotypic, phylogenetic, chemotaxonomic and genotypic results presented in this study demonstrate 


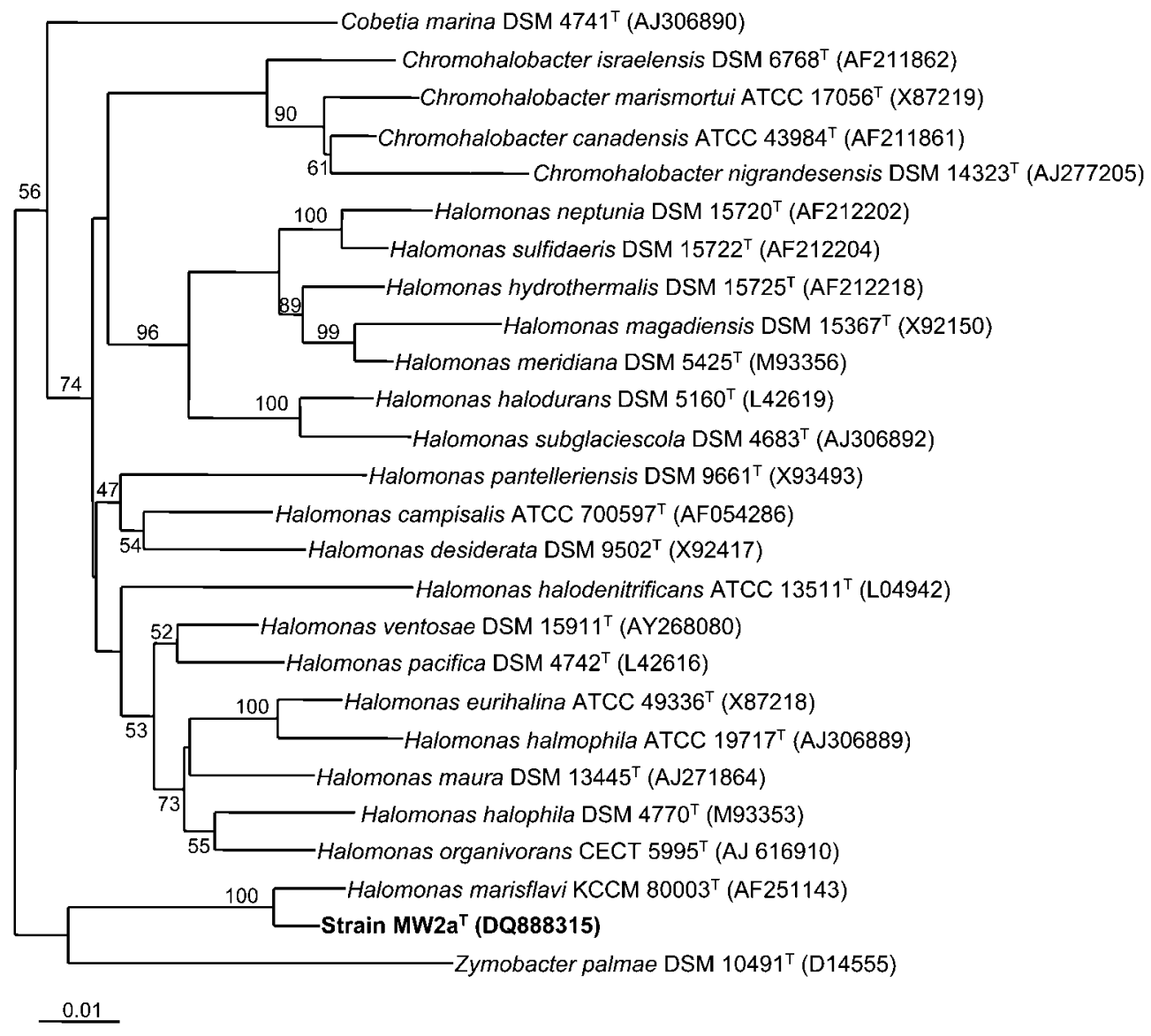

Fig. 1. Neighbour-joining distance tree based on the $16 \mathrm{~S}$ rRNA gene sequences of strain $M W 2 a^{\top}$ and closely related species. Bar, 1 substitution per 100 nucleotides. Bootstrap values greater than $40 \%$ are shown. Zymobacter palmae DSM $10491^{\top}$ was used as the outgroup.

that strain $\mathrm{MW} 2 \mathrm{a}^{\mathrm{T}}$ represents a novel species within the genus Halomonas, for which the name Halomonas avicenniae sp. nov. is proposed.

\section{Description of Halomonas avicenniae sp. nov.}

Halomonas avicenniae [a.vi.cen.ni'ae. N.L. n. Avicennia scientific name of a botanical genus which encompasses Avicennia germinans (the black mangrove); N.L. gen. $\mathrm{n}$. avicenniae of Avicennia, isolated from leaves of Avicennia germinans].

Cells are Gram-negative, motile, non-spore-forming short rods or oval-shaped, $2-2.6 \mu \mathrm{m}$ long and $1-2 \mu \mathrm{m}$ wide. Colonies are orange, smooth, circular/slightly irregular and convex, with an entire margin. Moderately halophilic, growing at $\mathrm{NaCl}$ concentrations in the range $0-25 \%(\mathrm{w} / \mathrm{v})$ with optimum growth at $5 \%(\mathrm{w} / \mathrm{v}) \mathrm{NaCl}$. Growth occurs at $12-40^{\circ} \mathrm{C}$ (optimum, $30-35^{\circ} \mathrm{C}$ ) and $\mathrm{pH} 5.0-9.0$ (optimum, $\mathrm{pH}$ 7.0-8.0). Strictly aerobic. Catalase-positive and gelatin and aesculin are hydrolysed. Production of indole and $\mathrm{H}_{2} \mathrm{~S}$, hydrolysis of starch, DNA and Tween 80 , and urease and oxidase are negative. Nitrate is not reduced. Acid is produced from D-glucose, sucrose, xylose, D-fructose and L-arabinose and weakly produced from maltose. Negative for arginine dihydrolase, ornithine decarboxylase and lysine decarboxylase. $\beta$-Galactosidase, $\beta$-glucosidase and $\alpha$-glucosidase activities are present. Negative for $\beta$-glucuronidase, $N$-acetyl- $\beta$-glucosaminidase, $\alpha$-galactosidase, $\alpha$-maltosidase and L-aspartic acid arylamidase. L-Arabinose, D-cellobiose, D-fructose, D-galactose, D-glucose, maltose, D-mannose and glycerol are used as carbon and energy sources. Shows intermediate resistance to erythromycin $(15 \mu \mathrm{g})$. Resistant to penicillin (10 units), bacitracin (10 units), cephalothin $(30 \mu \mathrm{g})$, tetracycline $(30 \mu \mathrm{g})$, rifampicin $(5 \mu \mathrm{g})$, streptomycin $(10 \mu \mathrm{g})$, neomycin $(30 \mu \mathrm{g})$, kanamycin $(30 \mu \mathrm{g})$, vancomycin $(30 \mu \mathrm{g})$, nalidixic acid $(30 \mu \mathrm{g})$, novobiocin $(30 \mu \mathrm{g})$ and chloramphenicol $(30 \mu \mathrm{g})$. Major fatty acids are $\mathrm{C}_{16: 0}$, $\mathrm{C}_{19: 0}$ cyclo $\omega 8 c, \mathrm{C}_{18: 1} \omega 7 c$ and $\mathrm{C}_{12: 0} 3-\mathrm{OH}$. The DNA G $+\mathrm{C}$ content of the type strain is $61.5 \mathrm{~mol} \%$.

The type strain is MW2 $\mathrm{a}^{\mathrm{T}}\left(=\right.$ CECT $\left.7193^{\mathrm{T}}=\mathrm{CCM} 7396^{\mathrm{T}}\right)$, which was isolated from the leaf surface of Avicennia germinans (black mangrove). 
Table 2. Cellular fatty acid compositions (\%) of strain $M W 2 a^{\top}$, the closely related species $H$. marisflavi and the type species of the genus, $H$. elongata

The strains were grown on SW10 medium for $24 \mathrm{~h}$ at $\mathrm{pH} 7.0$ and $30^{\circ} \mathrm{C}$. - , Not detected.

\begin{tabular}{|c|c|c|c|}
\hline Fatty acid & Strain $\mathrm{MW} 2 \mathrm{a}^{\mathrm{T}}$ & H. marisflavi КССМ $80003^{\mathrm{T}}$ & H. elongata ATCC $33173^{\mathrm{T}}$ \\
\hline $\mathrm{C}_{10: 0}$ & 1.0 & 2.4 & 4.7 \\
\hline $\mathrm{C}_{10: 0} 3-\mathrm{OH}$ & - & - & 3.6 \\
\hline $\mathrm{C}_{12: 0}$ & 0.8 & - & 4.7 \\
\hline $\mathrm{C}_{12: 0} 2-\mathrm{OH}$ & 3.2 & 3.2 & - \\
\hline $\mathrm{C}_{12: 0} 3-\mathrm{OH}$ & 11.3 & 11.0 & 15.3 \\
\hline $\mathrm{C}_{14: 0}$ & 0.4 & 0.5 & - \\
\hline $\mathrm{C}_{16: 1} \omega 7 c^{\star}$ & 2.6 & 3.5 & 4.5 \\
\hline$C_{16: 0}$ & 37.4 & 33.4 & 25.6 \\
\hline $\mathrm{C}_{16: 0} 3-\mathrm{OH}$ & - & - & 1.0 \\
\hline $\mathrm{C}_{17: 0}$ cyclo & 3.2 & 2.6 & 1.6 \\
\hline $\mathrm{C}_{17: 0}$ & - & - & 0.5 \\
\hline $\mathrm{C}_{18: 1} \omega 7 c$ & 16.6 & 25.7 & 25.6 \\
\hline $\mathrm{C}_{18: 0}$ & 1.2 & 2.1 & 0.6 \\
\hline $\mathrm{C}_{19: 0}$ cyclo $\omega 8 \mathrm{c}$ & 22.3 & 15.7 & 10.6 \\
\hline $\mathrm{C}_{19: 0}$ 10-methyl & - & - & 0.5 \\
\hline
\end{tabular}

${ }^{\star}$ Included in summed feature $3\left(\mathrm{C}_{16: 1} \omega 7 c\right.$ and/or iso- $\left.\mathrm{C}_{15: 0} 2-\mathrm{OH}\right)$.

\section{Acknowledgements}

The authors would like to thank Donato Seguí, Magaly Zapata, José Almodóvar and other members of Montalvo-Rodríguez's laboratory for technical assistance on this study. We would also like to thank Dr Jean P. Euzéby for his help with the etymology. This study was supported by grants from the Quality of Life and Management of Living Resources programme of the European Commission (Project 'Multigenome Access Technology for Industrial Catalysts', QLK3-CT2002-01972), Spanish Ministerio de Educación y Ciencia (BMC200301344) and from the Junta de Andalucia, and by the Dean of Arts and Sciences Seed Money programme at the University of Puerto RicoMayagüez Campus and the University of Puerto Rico AlaCiMa Program.

\section{References}

Arahal, D. R. \& Ventosa, A. (2005). The family Halomonadaceae. In The Prokaryotes: an Evolving Electronic Resource for the Microbiological Community, 3rd edn, release 3.20. Edited by M. Dworkin. New York: Springer.

Arahal, R. D., Garcia, M. T., Ludwig, W., Schleifer, K. H. \& Ventosa, A. (2001). Transfer of Halomonas canadensis and Halomonas israelensis to the genus Chromohalobacter as Chromohalobacter canadensis comb. nov. and Chromohalobacter israelensis comb. nov. Int J Syst Evol Microbiol 51, 1443-1448.

Arahal, R. D., Ludwig, W., Schleifer, K. H. \& Ventosa, A. (2002). Phylogeny of the family Halomonadaceae based on $23 \mathrm{~S}$ and $16 \mathrm{~S}$ rDNA sequence analyses. Int J Syst Evol Microbiol 52, 241-249.

Bauer, A. W., Kirby, W. M. M., Sherris, J. C. \& Turck, M. (1966). Antibiotic susceptibility testing by a standardized single disk method. Am J Clin Pathol 45, 493-496.

Baumann, L., Bowditch, R. D. \& Baumann, P. (1983). Description of Deleya gen. nov. created to accommodate the marine species Alcaligenes aestus, A. pacificus, A. cupidus, A. venustus, and Pseudomonas marina. Int J Syst Bacteriol 33, 793-802.
Bouchotroch, S., Quesada, E., del Moral, A., Llamas, I. \& Bejar, V. (2001). Halomonas maura sp. nov., a novel moderately halophilic, exopolysaccharide-producing bacterium. Int J Syst Evol Microbiol 51, $1625-1632$

Cowan, S. T. \& Steel, K. J. (1965). Manual for the Identification of Medical Bacteria. London: Cambridge University Press.

De Ley, J. \& Tijtgat, R. (1970). Evaluation of membrane filter methods for DNA-DNA hybridization. Antonie van Leeuwenhoek 36, 461-474.

Díaz-Muñoz, G. \& Montalvo-Rodríguez, R. (2005). Halophilic black yeast Hortaea werneckii in the Cabo Rojo Solar Salterns: its first record for this extreme environment in Puerto Rico. Caribb J Sci 41, 360-365.

Dobson, S. J. \& Franzmann, P. D. (1996). Unification of the genera Deleya (Baumann et al. 1983), Halomonas (Vreeland et al. 1980), and Halovibrio (Fendrich 1988) and the species Paracoccus halodenitrificans (Robinson and Gibbons 1952) into a single genus, Halomonas, and placement of the genus Zymobacter in the family Halomonadaceae. Int J Syst Bacteriol 46, 550-558.

Dussault, H. P. (1955). An improved technique for staining redhalophilic bacteria. J Bacteriol 70, 484-485.

Felsenstein, J. (1993). PHYLIP (phylogeny inference package), version 3.6. Department of Genome Sciences, University of Washington, Seattle, USA.

Franzmann, P. D., Wehmeyer, U. \& Stackebrandt, E. (1988). Halomonadaceae fam. nov., a new family of the class Proteobacteria to accommodate the genera Halomonas and Deleya. Syst Appl Microbiol 11, 16-19.

Garcia, M. T., Mellado, E., Ostos, J. C. \& Ventosa, A. (2004). Halomonas organivorans sp. nov., a moderate halophile able to degrade aromatic compounds. Int J Syst Evol Microbiol 54, 1723-1728.

Hebert, A. M. \& Vreeland, R. H. (1987). Phenotypic comparison of halotolerant bacteria: Halomonas halodurans sp. nov., nom. rev., comb. nov. Int J Syst Bacteriol 37, 347-350. 
Heyrman, J., Balcaen, A., De Vos, P. \& Swings, J. (2002). Halomonas muralis sp. nov., isolated from microbial biofilms colonizing the walls and murals of the Saint-Catherine chapel (Castle Herberstein, Austria). Int J Syst Evol Microbiol 52, 2049-2054.

Hezayen, F. F., Tindall, B. J., Steinbüchel, A. \& Rehm, B. H. A. (2002). Characterization of a novel halophilic archaeon, Halobiforma haloterrestris gen. nov., sp. nov., and transfer of Natronobacterium nitratireducens to Halobiforma nitratireducens comb. nov. Int J Syst Evol Microbiol 52, 2271-2280.

Johnson, J. L. (1994). Similarity analysis of DNAs. In Methods for General and Molecular Bacteriology, pp. 655-681. Edited by P. Gerhardt, R. G. E. Murray, W. A. Wood \& N. R. Krieg. Washington, DC: American Society for Microbiology.

Kämpfer, P. \& Kroppenstedt, R. M. (1996). Numerical analysis of fatty acid patterns of coryneform bacteria and related taxa. Can J Microbiol 42, 989-1005.

Kaye, J. Z., Márquez, M. C., Ventosa, A. \& Baross, J. A. (2004). Halomonas neptunia sp. nov., Halomonas sulfidaeris sp. nov., Halomonas axialensis sp. nov. and Halomonas hydrothermalis sp. nov.: halophilic bacteria isolated from deep-sea hydrothermal-vent environments. Int J Syst Evol Microbiol 54, 499-511.

Koser, S. A. (1923). Utilization of the salts of organic acids by the Colon-Aerogenes group. J Bacteriol 8, 493-520.

Lee, J.-C., Jeon, C. O., Lim, J.-M., Lee, S.-M., Lee, J.-M., Song, S.-M., Park, D.-J., Li, W.-J. \& Kim, C.-J. (2005). Halomonas taeanensis sp. nov., a novel moderately halophilic bacterium isolated from a solar saltern in Korea. Int J Syst Evol Microbiol 55, 2027-2032.

Lim, J.-M., Yoon, J.-H., Lee, J.-C., Jeon, C. O., Park, D.-J., Sung, C. \& Kim, C.-J. (2004). Halomonas koreensis sp. nov., a novel moderately halophilic bacterium isolated from a solar saltern in Korea. Int J Syst Evol Microbiol 54, 2037-2042.

Lugo, A. E. \& Snedaker, S. C. (1975). Properties of a mangrove forest in southern Florida. In Actas, International Symposium on Biological Management of Mangroves, pp. 170-212. Edited by G. Walsh, S. C. Snedaker \& H. Teas. Gainesville: University of Florida.

Maidak, B. L., Olsen, G. J., Larsen, N., Overbeek, R., McCaughey, M. J. \& Woese, C. R. (1996). The Ribosomal Database Project (RDP). Nucleic Acids Res 24, 82-85.

Marmur, J. \& Doty, P. (1962). Determination of the base composition of deoxyribonucleic acid from its thermal denaturation temperature. J Mol Biol 5, 109-118.

Martínez-Cánovas, M. J., Béjar, V., Martínez-Checa, F. \& Quesada, E. (2004). Halomonas anticariensis sp. nov., from Fuente de Piedra, a saline-wetland wildfowl reserve in Málaga, southern Spain. Int J Syst Evol Microbiol 54, 1329-1332.

Martínez-Checa, F., Bejar, V., Martínez-Cánovas, J., Llamas, I. \& Quesada, E. (2005). Halomonas almeriensis sp. nov., a moderately halophilic, exopolysaccharide-producing bacterium from Cabo de Gata, Almería, south-east Spain. Int J Syst Evol Microbiol 55, 2007-2011.

Mata, J. A., Martínez-Cánovas, J., Quesada, E. \& Béjar, V. (2002). A detailed phenotypic characterisation of the type strains of Halomonas species. Syst Appl Microbiol 25, 360-375.

Mellado, E., Moore, E. R. B., Nieto, J. J. \& Ventosa, A. (1995). Phylogenetic inferences and taxonomic consequences of $16 \mathrm{~S}$ ribosomal DNA sequence comparison of Chromohalobacter marismortui, Volcaniella eurihalina, and Deleya salina and reclassification of $V$. eurihalina as Halomonas eurihalina comb. nov. Int J Syst Bacteriol 45, 712-716.

Miller, L. T. (1982). Single derivation method for routine analysis of bacterial whole-cell fatty acid methyl esters, including hydroxy acids. J Clin Microbiol 16, 584-586.
Montalvo-Rodríguez, R., Vreeland, R. H., Oren, A., Kessel, M., Betancourt, C. \& López-Garriga, J. (1998). Halogeometricum borinquense gen. nov., sp. nov., a novel halophilic archaeon from Puerto Rico. Int J Syst Bacteriol 48, 1305-1312.

Montalvo-Rodríguez, R., López-Garriga, J., Vreeland, R. H., Oren, A., Ventosa, A. \& Kamekura, M. (2000). Haloterrigena thermotolerans sp. nov., a halophilic archaeon from Puerto Rico. Int J Syst Evol Microbiol 50, 1065-1071.

Mormile, M. R., Romine, M. F., Garcia, M. T., Ventosa, A., Bailey, T. J. \& Peyton, B. M. (1999). Halomonas campisalis sp. nov., a dentrifying, moderately haloalkaliphilic bacterium. Syst Appl Microbiol 22, 551-558.

Owen, R. J. \& Hill, L. R. (1979). The estimation of base compositions, base pairing and genome sizes of bacterial deoxyribonucleic acids. In Chemical Methods for Microbiologists, pp. 277-296. Edited by F. A. Skinner \& D. W. Lovelock. London: Academic Press.

Page, R. D. M. (1996). TREEVIEW: an application to display phylogenetic trees on personal computers. Comput Appl Biosci 12, 357-358.

Quillaguaman, J., Hatti-Kaul, R., Mattiasson, B., Alvarez, M. T. \& Delgado, O. (2004). Halomonas boliviensis sp. nov., an alkalitolerant, moderate halophile isolated from soil around a Bolivian hypersaline lake. Int J Syst Evol Microbiol 54, 721-725.

Romanenko, L. A., Schumann, P., Rohde, M., Mikhailov, V. V. \& Stackebrandt, E. (2002). Halomonas halocynthiae sp. nov., isolated from the marine ascidian Halocynthiae aurantium. Int J Syst Evol Microbiol 52, 1773-1782.

Seghal, S. N. \& Gibbons, N. E. (1960). Effect of metal ions on the growth of Halobacterium cutirubrum. Can J Microbiol 6, 165-169.

Simmons, J. S. (1926). A culture medium for differentiating organisms of typhoid-colon aerogenes groups and for isolation of certain fungi. J Infect Dis 39, 209.

Stackebrandt, E. \& Goebel, B. M. (1994). Taxonomic note: a place for DNA-DNA reassociation and 16S rRNA sequence analysis in the present species definition in bacteriology. Int J Syst Bacteriol 44, 846-849.

Ventosa, A., Quesada, E., Rodríguez-Valera, F., Ruiz-Berraquero, F. \& Ramos-Cormenzana, A. (1982). Numerical taxonomy of moderately halophilic Gram-negative rods. J Gen Microbiol 128, 1959-1968.

Ventosa, A., Nieto, J. J. \& Oren, A. (1998). Biology of moderately halophilic aerobic bacteria. Microbiol Mol Biol Rev 62, 504-544.

Ventosa, A., Gutiérrez, M. C., Kamekura, M. \& Dyall-Smith, M. L. (1999). Proposal to transfer Halococcus turkmenicus, Halobacterium trapanicum JCM 9743 and strain GSL-11 to Haloterrigena turkmenica gen. nov., comb. nov. Int J Syst Bacteriol 49, 131-136.

Vreeland, R. H., Litchfield, C. D., Martin, E. L. \& Elliot, E. (1980). Halomonas elongata, a new genus and species of extremely salttolerant bacteria. Int J Syst Bacteriol 30, 485-495.

Wayne, L. G., Brenner, D. J., Colwell, R. R., Grimont, P. A. D., Kandler, O., Krichevsky, M. I., Moore, L. H., Moore, W. E. C., Murray, R. G. E. \& other authors (1987). International Committee on Systematic Bacteriology. Report of the ad hoc committee on reconciliation of approaches to bacterial systematics. Int J Syst Bacteriol 37, 463-464.

Yoon, J.-H., Choi, S. H., Lee, K.-C., Kho, Y. H., Kang, K. H. \& Park, Y.-H. (2001). Halomonas marisflavae sp. nov., a halophilic bacterium isolated from the Yellow Sea in Korea. Int J Syst Evol Microbiol 51, 1171-1177.

Yoon, J.-H., Lee, K.-C., Kho, Y. H., Kang, K. H., Kim, C.-J. \& Park, Y.-H. (2002). Halomonas alimentaria sp. nov., isolated from jeotgal, a traditional Korean fermented seafood. Int J Syst Evol Microbiol 52, $123-130$. 